\title{
In-vitro efficacy of different antibiotics used in the treatment of bacteria isolated from bovine mastitis in South Khartoum
}

\author{
Altiyb Alamir Hummeda Ahmed ${ }^{1}$, Abdelrahman M. A. Saeed ${ }^{2 *}$ \\ Khartoum North, Sudan, North Africa \\ *Corresponding Author: Abdelrahman M. A. Saeed \\ Email: dr.amasaeed@yahoo.com
}

${ }^{1}$ PG Student, ${ }^{2}$ Associate Professor, Dept. of Pharmacology and Toxicology, Faculty of Veterinary Medicine, University of Khartoum,

\begin{abstract}
Mastitis is the most important disease in dairy farms worldwide causing significant economic losses. Sixty milk samples were collected from mastitic cows and submitted to the laboratory for further bacteriological examinations, Staphylococcus spp. (45\%), Bacillus spp. (22.5\%), Enterobacter spp. (14.5\%), Pseudomonas spp. (8\%), Acinobacter spp (5\%) and Micrococcus spp (5\%) were found in bacteriological examination of all milk samples. Staphylococcus aureus was the most prevalent among Staphylococci isolates (45\%), followed by Staphylococcus intermedius (22\%), Staphylococcus warneri (11\%), Staphylococcus hyicus (11\%), Staphylococcus chromogenes (11\%) and Staphylococcus lentus (11\%) Also Bacillus spp were found to be: Bacillus alvei (40\%) Bacillus thermophilus (20\%), Bacillus coagulans (20\%) and Bacillus firmus (20\%). Sensitivity tests were conducted using 12 different antibiotics including Tetracycline and Gentamicin. The sensitivity was determined for each antibiotic by using disc diffusion technique according to KirbyBauer method. The isolated bacteria were highly sensitive to Ciprofloxacin, Ifovluxtsen, Linezolid, Gentamicin and they were found to be resistant to Cloxacillin, Cephalexin, followed by Tetracycline, Lincomycin. Roxithromycin. This study showed that the most causative agent of mastitis in south Khartoum is Staphylococcus aureus. Hygienic practices procedure in dairy farm must be sustainable to reduce this disease and to be aware about the suitable antibiotics to be used using antibiotic sensitivity test. The present study was designed to investigate the sensitivity of different antibiotics against bacteria isolated from suspected mastitic cows in dairy farms in south Khartoum, Sudan.
\end{abstract}

Keywords: Staph. aureus, Bacillus, Antibiotics, Mastitis, Ceprofloxacin, Sensitivity.

\section{Introduction}

Mastitis is the inflammatory disease of mammary glands of ruminants which may cause partial or full damage to udder leading to permanent blocking of milk ducts. It is the most common reason for the use of antimicrobials in dairy cows. ${ }^{1,2}$ Antimicrobials have been used to treat mastitis for more than fifty years, but consensus about the most efficient, safe, and economical treatment is still lacking. ${ }^{3}$

Gentamicin is used extensively in the management of acute coliform mastitis, because $>90 \%$ of coliform isolates are susceptible to this drug in-vitro. Intramammary administration of gentamicin results in minimal inhibitory concentrations in milk. The efficacy of intramammary gentamicin as a treatment for acute coliform mastitis has not been studied, and the amount of gentamicin that diffuses into plasma after intramammary infusion during an acute infection is unknown. ${ }^{4}$

Tetracycline is one of the most extensively used antibiotics because of its relative safety, low cost, and broad-spectrum activity against Gram-positive, Gramnegative bacteria, and a typical organisms such as Mycoplasma. ${ }^{5}$ However, therapeutic outcomes generally do not match the results from in-vitro susceptibility tests for mastitis causing pathogens, this inefficacy has been considered to be due to some factors such as the limited knowledge of pharmacokinetic properties of tetracycline in lactating dairy cows, decreased antibiotic activity in the milk phase, and the appearance of resistant bacteria. ${ }^{6}$ It is difficult to produce and maintain therapeutic concentrations in the milk with many commonly used broad-spectrum antimicrobials such as oxytetracycline, trimethoprimsulphonamide and ceftiofur. ${ }^{7,8}$

This study was aimed to evaluate the efficacy of some antibiotics against different isolated bacteria from suspected mastitic cows in dairy farm in south Khartoum, Sudan.

\section{Materials and Methods Sampling}

Sixty samples were collected from suspected mastitic cows, clinical and chronic mastitis cases. Milk samples were taken under aseptic conditions and submitted to the laboratory for further bacteriological studies. Five $\mathrm{ml}$ of milk were collected in sterile disposable bottles. Identification and biochemical tests were done. ${ }^{9}$

\section{Sensitivity tests}

The sensitivity was determined by using disc diffusion technique according to Kirby-Bauer method. ${ }^{10}$ Commercially prepared antibiotic disc from different concentrations for each antibiotic: Ampicillin/sulbactam (AS) 30mcg, Levofloxacin (LE) $5 \mathrm{mcg}$, Linezolid (LZ) $30 \mathrm{mcg}$, Co-Trimoxole (BA) $25 \mathrm{mcg}$, Cephalexin (PR) $30 \mathrm{mcg}$, Cloxacillin (CX) 5mcg, Tetracycline (TE) $30 \mathrm{mcg}$, Roxithromycin (RF) $15 \mathrm{mcg}$, Cefotaxime (cf) $30 \mathrm{mcg}$, Lincomycin (LM) $2 \mathrm{mcg}$, ciprofloxacin (CP) $5 \mathrm{mcg}$ and Gentamycin (GM) 10mcg.

The disks were placed onto the surface of the diagnostic sensitivity test medium inoculated with the isolated bacteria suspension. The plates were then incubated at $37^{\circ} \mathrm{C}$ for 48 hour. 
The zones of inhibitions were measured using the average of diameter inhibition zone in millimeters (ADIZ).

\section{Results}

Bacteriological examination of all milk samples found the presence of: Staphylococcus spp. (45\%), Bacillus spp. (22.5\%), Enterobacteria spp (14.5\%), Pseudomonus spp (8\%), Acinobacter spp (5\%) and Micrococcus spp (5\%). Staphylococcus aureus, was the most prevalent among Staphylococci isolates (45\%), followed by Staphylococcus intermedius (22\%), as it has been shown in Fig. 1. Fig. 2.

Results of identification of Bacillus spp were shown in

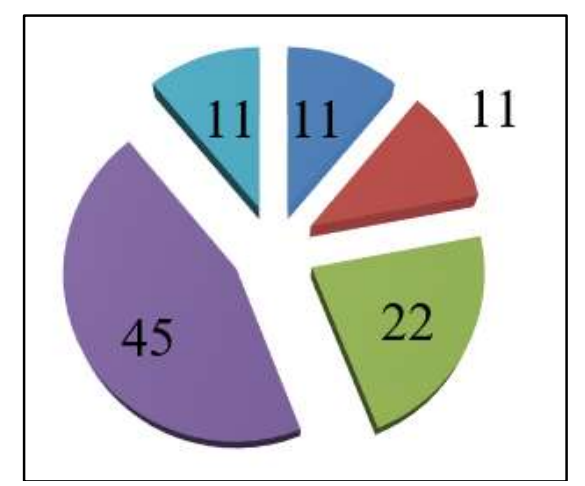

Fig. 1: Percentage of types of Staphylococcus spp isolated from mastitic cows

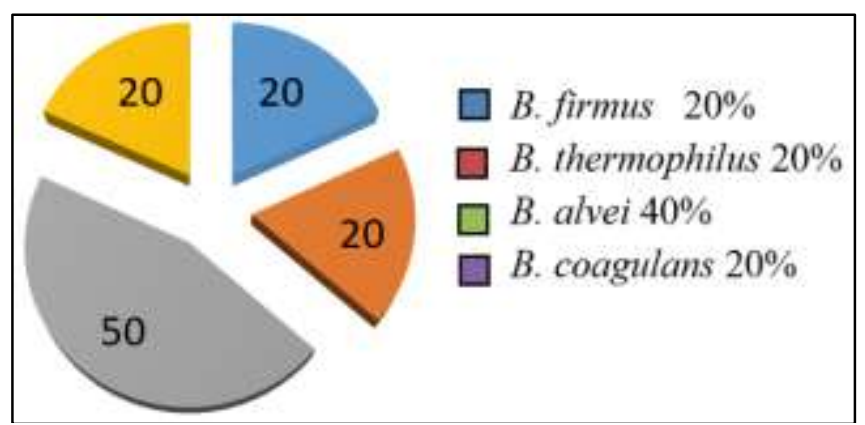

Fig. 2: Percentage of types of bacillus SPP isolated from mastitic cows

\section{Sensitivity test}

The inhibition zone results against different antibiotic was shown in table 1 and Fig. 3). All isolated bacteria were found to be highly resistance to Gentamycin. Tetracycline showed low efficacy and it had a highly percentage of resistant. Ciprofloxacin is the most effective antibiotic $(100 \%)$, this result makes it the drug of choice to treat mastitis cases in dairy cattle.

Table 1: Antibiotic sensitivity results against the isolated bacteria

\begin{tabular}{|l|l|l|}
\hline \multicolumn{1}{|c|}{ Drug } & \multicolumn{1}{|c|}{ Resistant isolates } & \multicolumn{1}{c|}{ Sensitive isolates } \\
\hline Ampicillin/sulbactam & $\begin{array}{l}\text { E.cloacae, B.thermophilus, B.alvei, } \\
\text { B.coagulans }\end{array}$ & $\begin{array}{l}\text { S.intermedius, S.warneri, S.aureus, S.hyicus, } \\
\text { B.firmus }\end{array}$ \\
\hline Co-Trimoxole & $\begin{array}{l}\text { E.cloacae, S.intermedius, B.firmus, } \\
\text { B.thermophilus, S.chromogenes, } \\
\text { B.coagulans }\end{array}$ & S.warneri, S.aureus, S.hyicus, B.alvei \\
\hline Cephalexin & E.cloacae, B.thermophilus, B.alvei & $\begin{array}{l}\text { S.intermedius, S.warneri, S.aureus, S.hyicus, } \\
\text { B.firmus, B.coagulans, S.chromogenes }\end{array}$ \\
\hline Tetracycline & $\begin{array}{l}\text { E.cloacae S.intermedius S.aureus } \\
\text { S.hyicus B.alvei, B.thermophilus, } \\
\text { S.chromogenes }\end{array}$ & B.coagulans, S.warneri, B.firmus \\
\hline Cefotaxime & $\begin{array}{l}\text { E.cloacae, S.warneri, B.firmus, } \\
\text { B.thermophilus, B.coagulans }\end{array}$ & $\begin{array}{l}\text { S.intermedius S.aureus S.hyicus B.alvei, } \\
\text { S.chromogenes }\end{array}$ \\
\hline Ciprofloxacin & no resistant isolates & all isolates were sensitive \\
\hline Levofloxacin & no resistant isolates & $\begin{array}{l}\text { S.intermedius, S.aureus, S.hyicus, S.chromogenes, } \\
\text { B.thermophilus, S.warneri B.firmus, B.coagulans. }\end{array}$ \\
\hline Linezolid & E.cloacae, B.alvei, & S.intermedius, S.warneri, S.chromogenes \\
\hline Cloxacillin & $\begin{array}{l}\text { E.cloacae, S.aureus, S.hyicus, } \\
\text { B.firmus, B.thermophilus, } \\
\text { B.coagulans, B.alvei }\end{array}$ & \\
\hline G.cloacae, S.hyicus. & $\begin{array}{l}\text { S.aureus, firmus, B.thermophilus, B.coagulans, } \\
\text { B.alvei, S.intermedius, S.warneri, S.chromogenes. }\end{array}$ \\
\hline Lentamicin & E.cloacae, S.intermedius, S.warneri & $\begin{array}{l}\text { S.aureus, S.hyicus, firmus, B.thermophilus, } \\
\text { B.coagulans, B.alvei, S.chromogenes }\end{array}$ \\
\hline Roxithromycin & $\begin{array}{l}\text { E.cloacae, S.intermedius, S.aureus, } \\
\text { S.hyicus, B.thermophilus, } \\
\text { B.coagulans }\end{array}$ & $\begin{array}{l}\text { B.alvei, S.chromogenes. } \\
\text { S.warneri, firmus. }\end{array}$ \\
\hline
\end{tabular}




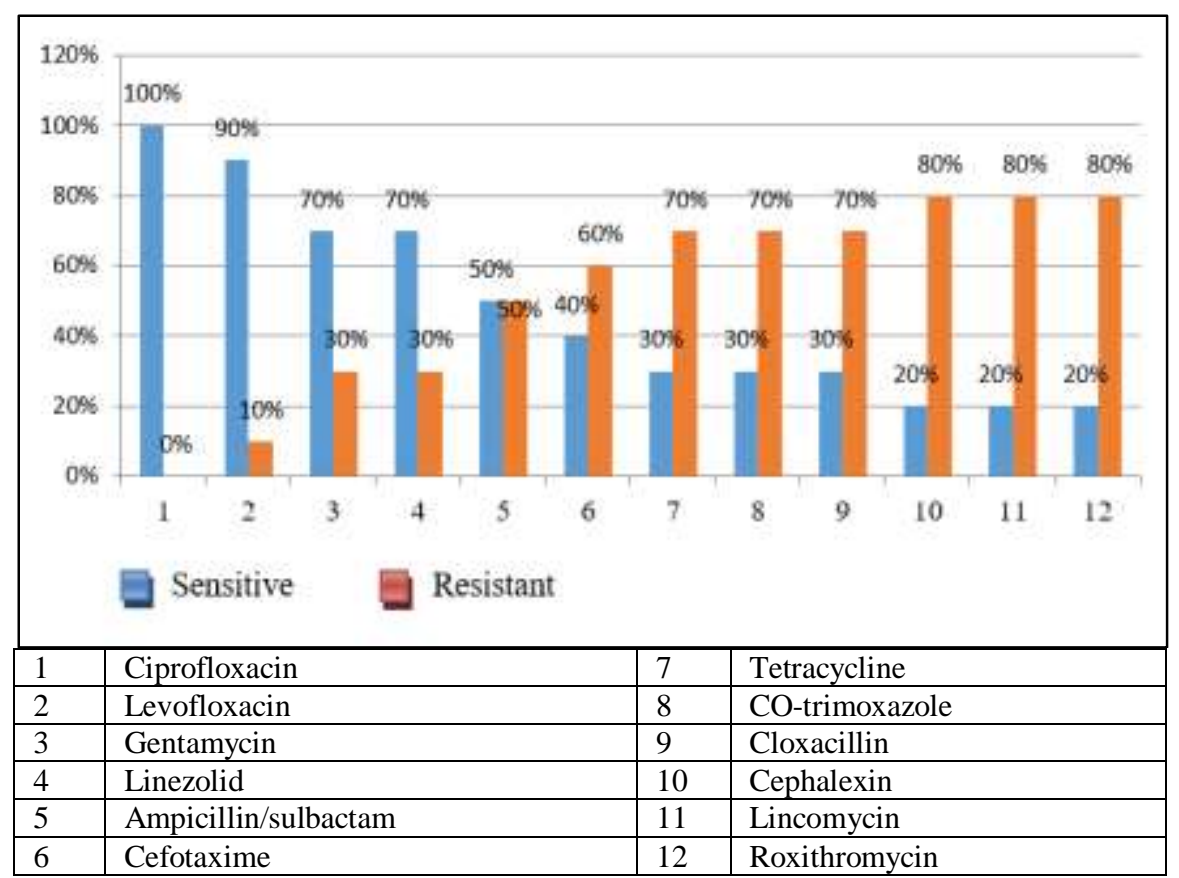

Fig. 3: Efficacy of the antibiotics against the isolated bacteria

\section{Discussion}

In this study, Staphylococcus aureus was the most frequent isolated pathogen (50\%). This might be attributed to the survival of this bacterium in variety environments. This result is in agreement with. ${ }^{11-18}$

The high incidence in our study might be attributed to increasing of numbers of animals per farm and also due to the spread of resistant strains.

While the isolation of Klebsiella spp., Enterococcus spp (10\%)., E.coli and Enterobacter spp. is attributed to poor or absence of hygiene. ${ }^{19}$ The failure of sanitary programme help the recovery of Bacillus spp., this suggestion is supported by other authors. ${ }^{20,21}$ The contribution of Pseudomonas spp in the causation of mastitis in this study is in agreement with other reports. ${ }^{16,21}$

In this study, Ciprofloxacin, Norfloxacin, Gentamicin and Streptomycin were found to be more effective against all isolated bacteria. These results are in agreement and supported with other report. ${ }^{23}$ While other researchers ${ }^{16}$ found that the isolates showed the highest resistance towards Penicillin, Collxacillin, Clindamycin and Ampicillin but Chloramphenicol showed the highest antimicrobial activity followed by Pipercillin and Gentamicin.

Sensitivity of Bacillus spp. was found to be as $70 \%$ for Gentamycin and 30\% for Tetracycline this finding was in agreement with different research. ${ }^{21}$

In previous studies, ${ }^{24}$ the sensitivity of numerous bacteria isolated from mastitic milk of cows to Penicillin, Amoxicillin and Tetracycline is in contrast to our result in this study. This might be due to absence of resistant strains.

\section{Conclusion}

It is concluded that the control of mastitis is an integrated procedures including, detection, identification of aetiological agents, proper treatment, proper sanitary measurements and proper veterinary services. If any of the above mentioned steps is overlooked this may lead to the spread of mastitis.

\section{Source of Funding}

None.

\section{Conflict of Interest}

None.

\section{References}

1. Mitchell JM, Griffiths M, McEwen SA. Antimicrobial drug residues in milk and meat: causes, concerns, prevalence, regulations, tests and test performance. J Food Protect. 1998;61:742-56.

2. Grave T, Greko C, Nilsson L. The usage of veterinary antibacterial drugs for mastitis in cattle in Norway and Sweden during 1990-1997. Prev Vet Med. 1999;42:45-55.

3. Cockcroft P and Holmes M (2003) Evidence-based veterinary medicine. (1st edn), Oxford UK, Blackwell Publishing.

4. Erskine J, Walker RD, Bolin CA, Bartlett PC, White DG. Trends in antibacterial susceptibility of mastitis pathogens during a seven-year period. J Dairy Sci. 2002;85:1111-8.

5. Al-Nazawi MH. Resistance and residues of antibacterial in dairy farm and diary production in Al-Hassa region, Saudi Arabia. J Med Sci. 2006;6:198-202.

6. Constable PD, Morin DE. Treatment of clinical mastitis using antimicrobial susceptibility profiles for treatment decisions. Vet Clin Food Anim. 2003;19:139-55.

7. Erskine RJ, Wilson RC, Tyler JW. Ceftiofur distribution in serum and milk from clinically normal cows and cows with experimental Escherichia coli - induced mastitis. Am J Vet Res. 1995;56:481-6. 
8. Kaartinen L, Löhönen K, Wiese B. Pharmacokinetics of sulphadiazine-trimethoprim in lactating dairy cows. Acta vet Scand 1999;40:271-8.

9. Barrow, G. I. and Feltham,RKA. (2003). Cowan and Steels Manual for Identification of Medical Bactreria. $3^{\text {rd }}(\mathrm{ed})$ Cambridge press.

10. Bauer AW, Kirby WMM, Sherris JC, Turck M (1966). Antibiotic susceptibility testing by standard single disc method. Am J Clin Pathol. 1966;45:493-6.

11. Bagadi HO. The etiology of bovine mastitis in three area in Sudan. Trop Animal Health Pord. 1970;2:28-34.

12. Adlan AM, Shommein AM, EI Amin EDM. (1980). A survey of Bovine mastitis in four dairy farms in the Sudan. Sudan J Vet. 1980;2:37-40.

13. Mamoun I, Bakheit MR. Bovine Staphylococcal Mastitis in the Sudan. Sudan J Vet Sci Anim Husb. 1992;31:62-4.

14. Salwa MS. Studies on camel, Atiology, clinical picture and milk --composition. Thesis MSc, university of Khartoum, Sudan; 1995.

15. Madut NA, Gadir AEA. (Susceptibility of Corynebacterum spp. Responsiblefor bovine mastits against commonly used antibiotics in Kuku dairy farms, Sudan. J Cell Anim Biol. 2011;5(1):6-10.

16. El Zubeir IEM, El Owni OAO. Antimicrobial resistance of bacteria associated with raw milk contaminated by chemical preservatives. World J Dairy Food Sci. 2009;4(1):65-9.

17. Madut NA, Abdel Gadir AE. Susceptibility of Corynebacterum spp. responsible for bovine mastits against commonly used antibiotics in Kuku dairy farms, Sudan. J Cell Animal Biol. 2011;5(1):6-10.
18. Junaidu, AU, Salihu MD, Tambuwala FM, Magaji AA, Jaafaru S. Advances in applied science research. 2011;2(2):290-4.

19. Sudhan NA, Singh R, Singh M, Soodan JS. Studies on prevalence, etiology and diagnosis of subclinical mastitis among cross bred cows. Indian J Animal Res. 2005;39(2):12730.

20. Quinn PJ, Carter ME, Markey BK. Mastitis. In: Quinn, PJ. (ed). Clinical Veterinary Microbiology. Wolfe, Baltimore. 1994;327-44.

21. Salih RRM, Ahmed FAM. Treatment Trial of Bovine Bacterial Mastitis in Khartoum State, Sudan. World's Vet J 2011;1(1):20-4.

22. Bardoel BW, Van der ES, Pel MJC, Tommassen J, Pieterse CMJ, van Kessel KPM., et al. Pseudomonas Evades Immune Recognition of Flagellinin Both Mammals and Plants. Plos Pathogen. 2011;7(8):1-11.

23. Mahantesh MK, Basappa BK. (2011). Prevalance and antimicrobial susceptibility of bactria isolated from bovine mastitis. Adv Appl Sci Res. 2011;228(6):229-35.

24. Wakeem AA, El Tyeb A. A survey of the causal organisms of chronic mastitis in a herd and its treatment with oxytetracycline. Sud J Vet Sci Anim Husb. 1962;3:28-32.

How to cite this article: Ahmed AAH, Saeed AMA. Invitro efficacy of different antibiotics used in the treatment of bacteria isolated from bovine mastitis in South Khartoum. Indian J Pharm Pharmacol 2020;7(1):39-42. 